\title{
Comparison of IL-6, IL-8 Concentrations in H. pylori- and non-H. pylori-associated Gastritis
}

\author{
Gontar Alamsyah Siregar ${ }^{1, *}$, Sahat Halim², Ricky Rivalino Sitepu² \\ ${ }^{1}$ Division of Gastroentero-Hepatology, Department of Internal Medicine, Faculty of Medicine, University of Sumatera Utara/ Adam Malik General \\ Hospital, Jl. Bunga Lau No.17, Medan, Indonesia \\ ${ }^{2}$ Department of Internal Medicine, Faculty of Medicine, University of Sumatera Utara/ Adam Malik General Hospital, Jl. Bunga Lau No.17, Medan, \\ Indonesia \\ *Corresponding author. E-mail: gontarsiregar@gmail.com
}

\section{Abstract}

$\mathrm{B}$ ACKGROUND: Helicobacter pylori is a noninvasive microorganism causing intense gastric mucosal inflammatory and immune reaction. The gastric mucosal levels of the proinflammatory cytokines Interleukin 6 (IL-6) and IL-8 have been reported to be increased in $H$. pylori infection, but the serum levels in $H$. pylori infection is still controversial. The purpose of this study was to investigate the serum levels of IL-6 and IL-8 in H. pylori infection.

METHODS: A cross sectional study was done on eighty consecutive gastritis patients admitted to endoscopy units at Adam Malik General Hospital and Permata Bunda Hospital, Medan, Indonesia from May-October 2014. Histopathology was performed for the diagnosis of gastritis. Rapid urease test for diagnosis of $H$. pylori infection. Serum samples were obtained to determine circulating IL-6 and IL-8. Univariate and bivariate analysis (independent $t$ test) were done.

RESULTS: There were $41.25 \%$ patients infected with $H$. pylori. Circulatory IL-6 levels were significantly higher in $H$. pylori-infected patients compared to $H$. pylori negative, but there were no differences between serum levels of IL-8 in H. pylori positive and negative patients.

CONCLUSION: The immune response to $H$. pylori promotes systemic inflammation, which was reflected in an increased level of serum IL-6. Serum levels of IL-8 were not significantly different between $H$. pylori positive and negative.

\section{Abstrak}

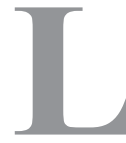

ATAR BELAKANG: Helicobacter pylori merupakan mikroorganisme non invasif yang menyebabkan inflamasi mukosa gaster dan reaksi imun. Kadar sitokin proinflamasi Interleukin 6 (IL-6) dan IL-8 di mukosa gaster telah dilaporkan meningkat pada pasien yang terinfeksi $H$. pylori. Sementara kadar sitokin proinflamasi di serum masih kontroversi. Tujuan penelitian ini untuk mengetahui kadar serum IL-6 dan IL-8 pada gastritis yang berkaitan dengan infeksi $H$. pylori.

METODE: Studi potong lintang secara prospektif terhadap 80 pasien gastritis secara konsekutif yang datang ke unit endoskopi Rumah Sakit Umum Adam Malik dan Rumah Sakit Permata Bunda, Medan, Indonesia dari Mei-Oktober 2014. Diagnosis gastritis dilakukan secara histopatologi. Rapid urease test digunakan untuk diagnosis infeksi $H$. pylori. Dilakukan pemeriksaan kadar serum IL-6 dan IL8. Dilakukan analisis univariat dan bivariat (independent $t$ test).

HASIL: Terdapat $41,25 \%$ pasien terinfeksi $H$. pylori. Kadar serum IL-6 lebih tinggi secara signifikan pada pasien yang terinfeksi $H$. pylori dibandingkan $H$. pylori negatif, sementara tidak ada perbedaan signifikan antara kadar serum IL-8 pada pasien dengan H. pylori positif dan negatif.

KESIMPULAN: Respons imun terhadap $H$. pylori menyebabkan inflamasi sistemik, seperti terlihat pada peningkatan kadar serum IL-6 secara signifikan. Kadar serum IL-8 tidak berbeda secara signifikan pada kedua kelompok. 
KEYWORDS: Helicobacter pylori, gastritis, IL-6, IL-8, cytokine

Indones Biomed J. 2014; 6(3): 163-6
KATA KUNCI: Helicobacter pylori, gastritis, IL-6, IL-8, sitokin

\section{Introduction}

Helicobacter pylori is the most common bacterial infection of humans that is specific for gastric epithelial cells. Depending on geographic location, $H$. pylori is inhabitant of half of the world population's stomach. H. pylori plays a crucial role in the development of gastrointestinal diseases such as chronic gastritis, gastric ulcer, and duodenal ulcer mucosa associated lymphoid tissue lymphoma and gastric adenocarcinoma. H. pylori is a non-invasive microorganism causing intense gastric mucosal inflammatory and immune reaction. $(1,2)$

Cytokines are responsible for orchestrating the immune response. $H$. pylori-induced gastric mucosal cytokine overproduction has been clearly documented previously. Local production of proinflammatory cytokines such as interleukin 6 (IL-6) and IL-8 are thought to play a central role in the recruitment of inflammatory cells to the gastric mucosa in the presence of $H$. pylori.(3)

Whether this inflammation is limited to gastric mucosa or causes systemic inflammation remains unclear. The stomach has a large surface area and continuous spillover of locally produced cytokines into the blood stream is a possibility. There are few and conflicting data on circulatory cytokine levels in patients with $H$. pylori infection. (4)

The purpose of the present study was to compare the serum levels of IL-6 and IL-8 as proinflammatory cytokines in $H$. pylori- and non- $H$. pylori-associated gastritis patients.

\section{Methods}

\section{Patient selection}

The present study was a cross sectional study on gastritis patients at Adam Malik General Hospital and Permata Bunda Hospital, Medan, Indonesia from May-October 2014. Eighty consecutive patients with gastritis admitted to endoscopy units were included in the study. All patients gave informed consent and the study was approved by the local ethic committee, No. 331/KOMET/FK USU/2014. None of the patients had received antibiotics, bismuth compounds, H2 antagonists, proton pump inhibitors or immune modulating drugs within the last four weeks before endoscopy. Patients with evidence of malignancy, immunosuppression, metabolic disorders, or gastrointestinal hemorrhage and patients who had a history of gastric surgery were excluded.

\section{Diagnosis of gastritis}

Diagnosis of gastritis was evaluated from biopsy of the mucosa of gastric antrum and body. The biopsy specimens were fixed in $10 \%$ formalin and embedded in paraffin. The samples were stained using Hematoxylin-Eosin and were evaluated by an anatomic pathologist from Faculty of Medicine, University of Sumatera Utara.

\section{Diagnosis of $\boldsymbol{H}$. pylori}

H. pylori was considered positive from the positive results of rapid urease test. Result of the rapid urease test was read within 24 hours.

\section{Serum levels of IL-6 and IL-8}

Venous blood was drawn using a serum separator tube and allowed to clot for 30-45 minutes at room temperature before centrifugation for 15 minutes at approximately $1,000 \mathrm{~g}$. Serum was immediately stored frozen in aliquots at $-20^{\circ} \mathrm{C}$ until assays for IL-6 and IL-8 were performed. IL-6 was assayed with Quantikine ELISA Human IL-6 Immunoassay (R\&D System, Minneapolis, MN, USA), while IL-8 was assayed with Quantikine HS ELISA Human CXCL8/IL-8 Immunoassay (R\&D System).

\section{Statistical analysis}

SPSS version 22 (SPSS Inc., Chicago) was used for the analysis. The data were analyzed using univariate and bivariate analysis with $95 \%$ confidence interval. Results are expressed as the mean $+/$ standard deviation. Bivariate analysis was carried out using independent t test. $\mathrm{p}</ 0.05$ was considered statistically significant.

\section{Results}

\section{Demographic of Respondents}

There were 80 subjects, consisted of 41 males $(51.25 \%)$ and 39 females (48.75\%). Mean of age was $49.3 \pm 13.4$ (SD) years old. The highest number of age group was from the age group of $46-60$. There were $41.25 \%$ patients infected 
with $H$. pylori. The majority of subject's employment status was housewife (36.25\%) and self-employed (32.5\%). The majority of the subjects had a normal nutrition status $(53.75 \%)$.

\section{Serum IL-6 and IL-8 levels in $\boldsymbol{H}$. pylori infection}

Mean serum levels of IL-6 and IL-8 were higher in H. pylori positive than $H$. pylori negative (Figure 1). Serum IL-6 level was significantly higher in infected group compared to H. pylori negative $(\mathrm{p}<0.05)$. Serum IL-8 level was higher in H. pylori positive than $H$. pylori negative $(38.96 \pm 25.92$ vs. $36.01 \pm 24.69)$, but not significant.

Table 1. Characteristics of the subjects.

\begin{tabular}{lccc}
\hline \multicolumn{1}{c}{ Variable } & $\begin{array}{c}\text { H. pylori } \\
\text { positive }\end{array}$ & $\begin{array}{c}\text { H. pylori } \\
\text { negative }\end{array}$ & Frequency \\
\hline Gender & & & \\
Male & $21(26.25 \%)$ & $20(25 \%)$ & $41(51.25 \%)$ \\
Female & $12(15 \%)$ & $27(33.75 \%)$ & $39(48.75 \%)$ \\
\hline Age (years) & & & \\
$<30$ & $5(6.25 \%)$ & $4(5 \%)$ & $9(11.25 \%)$ \\
$30-45$ & $10(12.5 \%)$ & $13(16.25 \%)$ & $23(28.75 \%)$ \\
$46-60$ & $10(12.5 \%)$ & $20(25 \%)$ & $30(37.5 \%)$ \\
$>60$ & $8(10 \%)$ & $10(12.5 \%)$ & $18(22.5 \%)$ \\
\hline Job & & & \\
Self employed & $11(13.75 \%)$ & $15(18.75 \%)$ & $26(32.5 \%)$ \\
Employee & $5(6.25 \%)$ & $7(8.75 \%)$ & $12(15 \%)$ \\
Farmer & $3(3.75 \%)$ & $3(3.75 \%)$ & $6(7.5 \%)$ \\
Housewife & $9(11.25 \%)$ & $20(25 \%)$ & $29(36.25 \%)$ \\
Other & $5(6.25 \%)$ & $2(2.5 \%)$ & $7(8.75 \%)$ \\
\hline
\end{tabular}

Nutritional status

Normal

$16(20 \%) \quad 27(33.75 \%) 43(53.75 \%)$

Under- \& Over-weight $17(21.25 \%) \quad 20(25 \%) \quad 37(46.25 \%)$

\begin{tabular}{|c|c|c|}
\hline Total & $33(41.25 \%) 47(58.75 \%)$ & $44(100 \%)$ \\
\hline
\end{tabular}

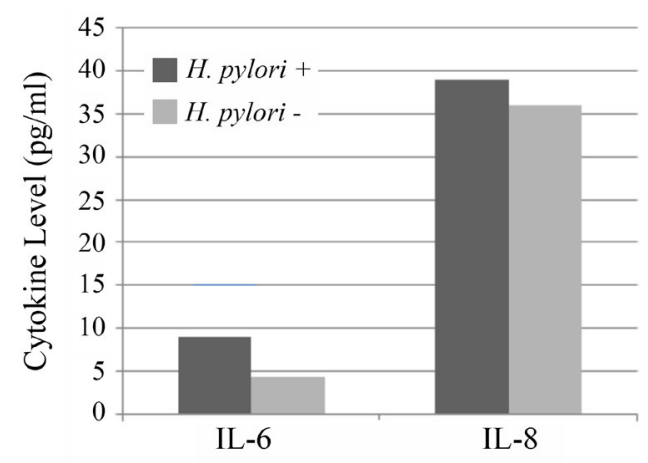

Figure 1. Mean Levels of IL-6 and IL-8 in H. pylori (+) and H. pylori (-) Patients.
Table 2. Serum level of IL-6 and IL-8 in $H$. pylori $(+)$ and H. pylori (-)

\begin{tabular}{cccc}
\hline $\begin{array}{c}\text { Serum Level } \\
(\mathbf{p g} / \mathbf{m l})\end{array}$ & $\begin{array}{c}\text { H. pylori positive } \\
(\text { mean } \pm \text { SD) }\end{array}$ & $\begin{array}{c}H . \text { pylori negative } \\
(\text { mean } \pm \text { SD) }\end{array}$ & $\begin{array}{c}\text { Independent } \\
\text { t test }\end{array}$ \\
\hline IL-6 & $9.06 \pm 9.49$ & $4.39 \pm 5.31$ & $0.014^{*}$ \\
IL-8 & $38.96 \pm 25.92$ & $36.01 \pm 24.69$ & 0.611 \\
\hline * $<0.05$ & & &
\end{tabular}

\section{Discussion}

Mean age of gastritis subjects in this study was $49.3 \pm 13.4$ (SD) years old, which is considered a productive age group. In addition, the age groups with the most cases of gastritis were those in the age group of 46-60 and 30-45. This result is in accordance with the results from the previous studies such as that by Garg B, et al., which reported the mean age of gastritis patients was 47 years and the study by Mustapha SK, et al., which reported a mean age of 47.2 years. $(5,6)$

The majority of previous studies on cytokines have focused on patients with severe gastritis or peptic ulcer. In this study, a group of patients with gastritis without major gastric diseases, such as peptic ulcer and gastric cancer, was examined with the purpose to describe gastritis in patients with or without $H$. pylori infections. Both clinical trial and population based epidemiologic studies achieved conflicting results about blood levels of inflammation markers in $H$. pylori infection. This study concern about serum levels of IL-6 and IL-8 as proinflammatory cytokine in $H$. pyloriinfected patients without systemic diseases.

H. pylori is the major recognized etiological agent inducing gastric inflammatory responses. These responses can be considered to have two components: chronic inflammatory responses associated with increased numbers of mononuclear cells in the lamina propria infiltration, including lymphocytes, monocytes/macrophages, and plasma cells; and acute inflammatory response characterized by intraepithelial and interstitial neutrophilic. These two responses may be regulated differentially following induction of cytokines involved in the inflammatory cascade. IL-6 may be involved in chronic inflammatory changes through its broad effects on growth and differentiation of mononuclear cells, including $\mathrm{T}$ and $\mathrm{B}$ lymphocytes and macrophages. IL-6 correlated strongly with the mononuclear cell density. $(3,7,8)$

Yamaoka et al. showed that mucosal IL-6 levels were higher in early gastric cancer with active $H$. pylori infection than without $H$. pylori infection.(9) Lindholm et al. could also detect increased levels of mucosal IL- 6 in the $H$. pyloriinfected subjects.(10) This study found that circulating level 
of IL-6 was significantly higher in infected group compared to $H$. pylori negative. Other study reported the same result. Nakagawa et al. reported that higher H. pylori IgG levels were significantly associated with higher serum IL-6 levels among H. pylori-infected individuals.(11)

Several investigators have showed that IL-8 is an important mediator in $H$. pylori-associated gastritis. In contrast to IL-6, IL-8 is specifically implicated in the pathogenesis of infectious and inflammatory conditions associated with neutrophil infiltration because of its potent chemotactic and stimulatory activity for neutrophils. IL-8 is the most likely substance responsible for inducing further steps of the signal transducing pathway because it is upregulated in epithelial cells due to $H$. pylori infection. $(7,8)$ Lindholm et al. found increased levels of mucosal IL-8 in the $H$. pylori-infected subjects.(10) Fan et al. showed that the concentrations of IL- 8 in gastric juice and gastric biopsy homogenates were substantially greater in patients infected with $H$. pylori, but there were no significant differences of IL-8 concentrations between $H$. pylori positive and negative patients.(12)

Cichoz-Lach et al. found that mean level of IL-8 in patients with biliary gastritis was higher than the control group, and was more increased in $H$. pylori infected patients than in uninfected ones. In erosive gastritis accompanied by $H$. pylori infection mean level of IL- 8 was higher than in uninfected patients for which the level was normal. (13) This study also found that serum levels of IL-8 were higher in $H$. pylori-associated gastritis, but not significant compared to H.pylori negative. Kim et al. showed that H. pylori strains that express cytotoxin-associated gene A (CagA) were found to upregulate epithelial IL-8 secretion and gene expression, a direct CagA effect on IL-8 induction by gastric epithelial cells. $(14,15)$ We did not determine the CagA status of our patients. This can be our limitation for this study, so we possibly had patients infected with less pathogenic strains of this bacterium such as with CagAnegative $H$. pylori. This might be a reason that there were no significant differences between serum levels of IL-8 in H. pylori positive and negative. Our findings suggest that a strong immune response to $H$. pylori enhanced the systemic inflammation, which was reflected in an increased level of serum IL-6.

\section{Acknowledgement}

We thank to the Prodia Education and Research Institute for the invaluable support to this study.

\section{References}

1. McColl KE. Clinical practice. Helicobacter pylori infection. N Engl J Med. 2010; 362: 1597-1604.

2. Yeniova AÖ, Kucukazman M, Ata N, Dal K, Kefeli A, Basyigit S, et al. The relationship between Helicobacter pylori and beta-2 microglobulin in humans. Biomed Res Int. 2014; 2014: 615089. doi: 10.1155/2014/615089.

3. Gatti LL, Burbano RR, Zambaldi-Tunes M, de-Lábio RW, de Assumpção PP, de Arruda Cardoso-Smith M, et al. Interleukin-6 Polymorphisms, Helicobacter pylori infection in adult Brazilian patients with chronic gastritis and gastric Adenocarcinoma. Arch Med Res. 2007; 38: 551-5.

4. Bayraktaroğlu T, Aras AS, Aydemir S, Davutoğlu C, Ustündağ $\mathrm{Y}$, Atmaca $\mathrm{H}$, et al. Serum levels of tumor necrosis factor-alpha, interleukin-6 and interleukin-8 are not increased in dyspeptic patients with Helicobacter pylori-associated gastritis. Mediators Inflamm. 2004; 13: 25-8.

5. Garg B, Sandhu V, Sood N, Sood A, Malhotra V. Histopathological analysis of chronic gastritis and correlation of pathological features with each other and with endoscopic findings. Pol J Pathol. 2012; 63: 172-8.

6. Mustapha S, Bolori M, Ajayi N, Nggada H, Pindiga U, Gashau W, et al. Endoscopic findings and the frequency of Helicobacter pylori among dyspeptic patients in North-Eastern Nigeria. Internet $\mathrm{J}$ Gastroenterol. 2006; 6(1).

7. Kusters JG, van Vliet AH, Kuipers EJ. Pathogenesis of Helicobacter pylori infection. Clin Microbiol Rev. 2006; 19: 449-90.

8. Banerjee A, Mukhopadhyay AK, Paul S, Bhattacharyya A, Swarnakar S. Unveiling the Intricacies of Helicobacter pylori-induced Gastric Inflammation: $\mathrm{T}$ Helper cells and Matrix Metalloproteinases at a Crossroad. In: Mozsik G, editor. Current Topics in Gastritis. Croatia: InTech Publishers; 2013. Chapter 7.

9. Yamaoka Y, Kodama T, Kita M, Imanishi J, Kashima K, Graham DY. Relation between cytokines and Helicobacter pylori in gastric cancer. Helicobacter 2001; 6: 116-24.

10. Lindholm C, Quiding-Jarbrink M, Lonroth H, Hamlet A, Svennerholm AM. Local cytokine response in Helicobacter pylori-infected subjects. Infect Immun. 1998; 66: 5964-71.

11. Nakagawa H, Tamura T, Mitsuda Y, Goto Y, Kamiya Y, Kondo T, et al. Significant Association between serum interleukin-6 and Helicobacter pylori antibody levels among H. pylori-positive Japanese adults. Mediators Inflamm. 2013; 2013: 142358. doi: $10.1155 / 2013 / 142358$.

12. Fan XG, Chua A, Fan XJ, Keeling PW. Increased gastric production of interleukin- 8 and tumour necrosis factor in patients with Helicobacter pylori infection. J Clin Pathol. 1995; 48:133-6.

13. Cichoz-Lach H, Słomka M, Celiński K, Baczek A. Level of serum cytokines in biliary gastritis and erosive gastritis with Helicobacter pylori coinfection. Ann Univ Mariae Curie Sklodowska Med. 2001; 56: 271-4.

14. Kim SY, Lee YC, Kim HK, Blaser MJ. Helicobacter pylori CagA transfection of gastric epithelial cells induces interleukin-8. Cell Microbiol. 2006; 8: 97-106.

15. Meine GC, Rota C, Dietz J, Sekine S, Prolla JC. Relationship between caga-positive Helicobacter pylori infection and risk of gastric cancer: a case control study in Porto Alegre, RS, Brazil. Arq Gastroenterol. 2011; 48: 41-5. 